\title{
Analisisi Energi Listrik Terselamatkan pada Penyulang Bangli PT. PLN (Persero) Area Bali Timur dengan Beroperasinya PLTS Kayubihi
}

\author{
Valentinus Gerald ${ }^{1}$, Rukmi Sari Hartati ${ }^{2}$, Antonius Ibi Weking ${ }^{3}$
}

\begin{abstract}
Bangli Feeder has 3 Feeder, namely Kota Feeder, Kayubihi Feeder and Tembuku Feeder. This Feeder has a main power supply is obtained from the Gianyar Main Relay Station. Currently Kayubihi Solar Cell Power Plant directly interconnected to the Feeder Bangli. With Solar cell power plant connected on Kayubihi Feeder, it will result in a change in the performance of feeder Bangli. This involves changes in the performance of of the electrical energy that is channeled along the Bangli feeder system reliability. The addition of the feeder solar cell power plant create electrical energy saved Bangli feeder decline. Bangli feeder without generating large solar power energy not supplied amounted to $10.426 \mathrm{kWh}$. Energy not supplied Bangli Feeder after obtaining additional supplies of solar power generating is $1.505 \mathrm{kWh}$.
\end{abstract}

Intisari-Penyulang Bangli memiliki 3 Feeder, yaitu Feeder Kota, Feeder Kayubihi dan Feeder Tembuku. Penyulang ini memiliki suplai daya utama yang didapatkan dari GI Gianyar. Saat ini terhubung PLTS yang terinterkoneksi langsung pada penyulang Bangli. Dengan adanya PLTS yang terhubung pada Feeder Kayubihi, maka akan berakibat pada berubahnya performa penyulang Bangli. Perubahan performa ini menyangkut tentang energi listrik yang tersalurkan serta keandalan sistem penyulang Bangli tersebut. Penambahan PLTS pada penyulang Bangli membuat energi listrik terselamatkan Penyulang Bangli mengalami penurunan. Penyulang Bangli tanpa PLTS menghasilkan besar energy not supplied sebesar $10.426 \mathrm{kWh}$. ENS Penyulang Bangli setelah mendapat pasokan tambahan dari PLTS menghasilkan $1.505 \mathrm{kWh}$.

Kata Kunci-Section Technique, RIA, gabungan metode, Indeks Keandalan.

\section{PENDAHULUAN}

Energi listrik merupakan salah satu energi yang sangat diperlukan oleh semua golongan masyarakat untuk menunjang aktivitas sehari-hari. Seiring perkembangan zaman dengan era globalisasi, perkembangan teknologi dan industri-industri besar yang menggunakan energi listrik pun semakin menjamur sehingga kebutuhan listrik setiap tahun terus meningkat. [1].

${ }^{1}$ Mahasiswa, Jurusan Teknik Elektro dan Komputer Fakultas Teknik Universitas Udayana, Jln. Muding Pertiwi No. 17 Kerobokan 80361 INDONESIA (tlp: 085792007585; e-mail: budi.arigandhi@gmail.om)

${ }^{2}$ Dosen, Jurusan Teknik Elektro dan Komputer Fakultas Teknik Universitas Udayana, Jln. Kertha Petasikan 1/4 Denpasar (telp: 081238203599; e-mail: rshartati@unud.ac.id)

${ }^{3}$ Dosen, Jurusan Teknik Elektro dan Komputer Fakultas Teknik Universitas Udayana, Jln. Panji No. 8 Banjar Kwanji Dalung (telp: 081236476536; e-mail:tony@unud.ac.id)
Di Indonesia saat ini sudah banyak pembangkit yang memanfaatkan energi sinar matahari untuk menghasilkan energi listrik untuk menambah pasokan tenaga listrik pada suatu daerah yang kekurangan pasokan tenaga listrik. Barubaru ini telah dibangun salah satu pembangkit listrik tenaga surya (PLTS) di provinsi Bali tepatnya dibangun di Desa Bangklet di atas tanah seluas 1,2 Ha di Kabupaten Bangli. Pembangkit listrik tenaga surya merupakan sumbangan pemerintah kepada pihak PLN dalam rangka mendukung penggunaan energi terbarukan sebagai energi untuk membangkitkan listrik.

PLTS ini memiliki daya mampu sebesar $1 \mathrm{MW}$ dan langsung terinterkoneksi (terhubung) pada sistem jaringan penyulang Bangli khususnya pada Feeder Kayubihi. Seluruh daya listrik yang dibangkitkan oleh PLTS ini langsung disalurkan pada sistem jaringan penyulang Bangli tanpa adanya baterai untuk menyimpan energi listrik (esdm.go.id). Suplai daya utama penyulang Bangli didapatkan dari GI Gianyar. Kondisi existing saat ini, sistem jaringan penyulang Bangli memiliki 3 Feeder, yaitu Feeder Kota, Feeder Kayubihi dan Feeder Tembuku [3].

Di dalam penelitian ini akan mengetahui indeks ENS dan AENS sistem dapat dilakukan analisis energi listrik yang disalurkan peralatan distribusi yang memiliki dampak terhadap penjualan energi. Analisis energi listrik terselamatkan dari sisi PLN dilakukan berdasarkan besar indeks ENS (Energy Not Supplied) dan tarif dasar penjualan energi yang ditetapkan oleh PLN sebagai penyedia energi listrik . Dari hasil analisis nilai ini secara komprehensif dapat dikorelasikan dengan aspek keandalannya sehingga dapat dievaluasi kembali peralatan distribusi yang terpasang untuk memperkecil kerugian yang terjadi di PLN.

Penyulang Bangli memiliki tipe jaringan radial, dengan panjang saluran $78,963 \mathrm{~km}$. Selain itu, penyulang ini memiliki trafo distribusi sebanyak 137 buah dengan total jumlah pelanggan mencapai 20.700 pelanggan. Penyulang untuk tahun 2014. Untuk tahun 2015 Penyulang Bangli memiliki 150 trafo distribusi dengan pelanggan penyulang mencapai 22.979 pelanggan.

\section{ENERGI LISTRIK TERSELAMATKAN}

\section{A. ASIDI (AVERAGE SYSTEM INTERRUPTION DURATION} INDEX) :

ASIDI merupakan indeks keandalan yang memiliki persamaan dengan SAIDI, namun ASIDI memiliki nilai berdasarkan daya gangguan yang terkoneksi pada seluruh system [5]: 
$\mathrm{ASIDI}=\frac{k V a \text { durasi gangguan terkoneksi }}{k V a \text { system }}$

\section{B. ASIFI (AVERAGE SYSTEM INTERRUPTION FREQUENCY INDEX)}

ASIFI merupakan indeks keandalan yang memiliki persamaan dengan SAIFI, namun ASIFI memiliki perhitungan berdasarkan daya gangguan yang terkoneksi pada seluruh sistem [5].

$$
\mathrm{ASIFI}=\frac{k \text { Va gangguan terkoneksi }}{k V a \text { system }}
$$

$$
\begin{aligned}
& \text { C. } \mathrm{NDE}(\text { NON DELIVERY ENERGY) [6] } \\
& \qquad \begin{array}{l}
\mathrm{NDE}=\mathrm{P}_{\mathrm{C}} \times \mathrm{t}_{\mathrm{CA}}
\end{array}
\end{aligned}
$$

Dimana :

NDE : Jumlah total energi yang tidak terkirim dalam durasi waktu tertentu.

$\mathrm{P}_{\mathrm{C}} \quad$ : Jumlah total energi yang tidak terkirim

$\mathrm{T}_{\mathrm{CA}}$ : Durasi waktu pemadaman

\section{AENS (AVERAGE ENERGY NOT SUPPLIED)}

AENS (Average Energy Not Supplied) merupakan jumlah rata-rata energi listrik yang tidak tersalurkan dalam suatu sistem distribusi tiap tahun. Hal ini didefinisikan sebagai rasio dari total energi yang tidak diberikan untuk jumlah pelanggan [5].

$$
\text { AENS }=\frac{\text { Energi Total yang tak tersalurkan sistem }}{\text { Total pelanggan yang dilayani }}
$$

Dimana AENS dapat dikerucutkan menjadi indeks ENS (Energy Not Supplied) yang merupakan penjumlahan dari daya yang tidak tersuplai kepada pelanggan selama periode satu tahun. Ini didefinisikan sebagai penjumlahan energi tidak diberikan karena gangguan terhadap pasokan daya selama periode tahun.

$$
\text { ENS }=\sum[\text { Gangguan }(\mathrm{kW}) \times \text { Durasi }(\mathrm{h})]
$$

\section{E. LOAD FACTOR}

Faktor beban (load factor) didefinisikan sebagai perbandingan antara beban rata-rata dengan beban puncak yang diukur untuk suatu periode waktu tertentu.

$$
F_{L D}=\frac{B_{r}(\text { beban rata rata })}{B_{p}(\text { beban puncak })}
$$

Pada persamaan tersebut beban rata-rata akan selalu bernilai lebih kecil dari kebutuhan maksimum atau beban puncak, sehingga faktor beban akan selalu lebih kecil dari 1 (satu) [3].

\section{F. LOSS FACTOR}

Perhitungan susut energi tahunan secara empiris dapat dilakukan dengan menggunakan konstanta yang disebut dengan loss factor. Loss factor ditentukan dari pola beban harian pada sistem yang akan diteliti [3]. Loss factor dihitung dengan menggunakan persamaan berikut:

$$
\mathrm{F}_{\mathrm{LS}}=0.15 \mathrm{~F}_{\mathrm{LD}}+(1-0.15) \mathrm{F}_{\mathrm{LD}}^{2}
$$

Dimana:

$$
\begin{array}{ll}
\mathrm{F}_{\mathrm{LS}} & =\text { Loss factor } \\
\mathrm{F}_{\mathrm{LD}} & =\text { Load factor }
\end{array}
$$

\section{G. SUSUT ENERGI}

Untuk perhitungan susut energi digunakan persamaan dengan parameter rugi tembaga dan rugi beban kuadrat. Rugi tembaga atau rugi-rugi lainnya berbanding lurus dengan kuadrat beban dan dengan adanya kurva beban dengan waktu atau kurva lamanya pembebanan, maka dapatlah dibuat kurva rugi daya dibagi waktu atau kurva lamanya rugi daya dimana setiap ordinatnya berbanding lurus dengan kuadrat setiap ordinat kurva bebannya. Dari kurva lamnya rugi daya, dapat pula ditentukan rugi daya rata-ratanya selama periode tersebut. Luas dari kurva lamanya rugi daya merupakan rugi energi selama periode tersebut [4]. Dalam perhitungan rugi energi sebaiknya dipakai faktor rugi yaitu perbandingan antara rugi daya rata-rata dan rugi daya pada beban puncak dalam periode tertentu. Jadi rugi daya rata-rata (susut energi) adalah

Susut energi $=$ Rugi Daya pada Beban Puncak $\times$ Loss Factor $\times 8760$

Dimana : 8760 merupakan periode jam dalam satu tahun (365 hari x 12 bulan)

\section{METODE PENELITIAN}

Penelitian ini mengambil contoh sistem distribusi pada wilayah kerja PT. PLN (Persero) Area Bali Timur, tepatnya di Penyulang Bangli, dimana penyulang ini merupakan salah satu penyulang tipe radial dalam area PT. PLN (Persero) Distribusi Area Bali Timur Rayon Bangli. Penelitian dimulai pada bulan Juli hingga November 2015. Data yang dikumpulkan bersifat data sekunder. Data yang digunakan dalam analisis penelitian ini adalah :

- $\quad$ Single line diagram Penyulang Bangli

- Data jumlah pelanggan untuk tiap titik beban

- Data panjang saluran penyulang

- Parameter pada tiap komponen dalam menganalisis keandalan sistem, seperti : Laju Kegagalan $(\lambda)$, Waktu Perbaikan (r), Waktu Pemindahan (rs), angka keluaran peralatan (Outage) dan waktu operasi kerja pemulihan pelayanan komponen sistem distribusi.

- Data Tarif Dasar Listrik (TDL) terbaru yang ditetapkan PLN sesuai dengan TARIF Adjustment PLN per Desember 2015. 
- Data pembangkitan PLTS Kayubihi dan beban puncak Penyulang Bangli.

Alur analisis dari penelitian ini adalah sebagai berikut :

1. Studi Kepustakaan dengan pengolahan data dilakukan dengan membaca literatur-literatur yang berhubungan dengan ketenagalistrikan sistem distribusi, struktur jaringan radial, metode-metode dalam menganalisis indeks keandalan seperti ASIDI, ASIFI, ENS dan AENS.

2. Metode Obeservasi dengan mengumpulkan data-data Penyulang Bangli diperoleh langsung dari PT. PLN (Persero) Distribusi Bali Area Bali Timur, yang kemudian data tersebut akan digunakan untuk menganalisis indeks energi listrik Penyulang Bangli.

3. Melakukan perhitungan Energi Terselamatkan dengan melakukan dengan perhitungan besar daya listrik yang tidak disuplai pada waktu pemadaman (AENS dan ENS) di tiap-tiap titik beban yang diperoleh.

\section{HASIL DAN PEMBAHASAN}

\section{A. Perhitungan Energi Listrik Terselamatkan}

Pada awal langkah pertama di dalam menganalisis energi listrik terselamatkan pada penyulang Bangli adalah mengetahui jumlah pelanggan yang dilayani pada tiap titik beban, data jumlah pelanggan yang mengalami gangguan, jumlah daya yang terpakai, daya pelanggan gangguan dan lama waktu perbaikan (repair time) pada penyulang Bangli yang akan digunakan untuk menghitung energi listrik terselamatkan menggunakan indeks ASIDI, ASIFI, ENS dan AENS pada penyulang Bangli sebelum dan sesudah beroperasinya PLTS Kayubihi.

\section{B. Energi Listrik Terselamatkan Penyulang Bangli Sebelum mendapat pasokan PLTS Kayubihi}

Sistem Distribusi Jaringan penyulang Bangli merupakan jaringan sistem distribusi $20 \mathrm{kV}$ dengan 3 feeder, yaitu feeder Kota, feeder Kayubihi dan feeder Tembuku dari 137 transformator distribusi. Penyulang Bangli mendapatkan suplai daya utama dari GI Gianyar trafo 2 dengan kapasitas daya sebesar 30 MVA. Penyulang ini mensuplai energi ke konsumen kota Bangli dengan pelanggan mencapai 20.700 pelanggan.

Energi listrik terselamatkan pada penyulang Bangli menggunakan parameter-parameter data berupa pelanggan yang dilayani tiap titik beban, pelanggan yang mengalami gangguan, jumlah daya yang terpakai, daya gangguan dan lama waktu pemadaman pada penyulang Bangli menggunakan indeks ASIDI, ASIFI, ENS (Energy Not Supplied), dan AENS (Average Energy Not Supplied).

Valentinus Gerald: Analisis Energi Listrik Terselamatkan ...
Tabel 1.

Kondisi Penyulang Bangli sebelum mendapat pasokan PLTS Kayubihi

\begin{tabular}{|c|c|c|c|c|}
\hline $\begin{array}{c}\text { JUMLAH } \\
\text { GARDU }\end{array}$ & $\begin{array}{c}\text { PELANG } \\
\text { GAN }\end{array}$ & $\begin{array}{c}\text { PELANGGAN } \\
\text { INTERRUPT }\end{array}$ & $\begin{array}{c}\text { TOTAL } \\
\text { DAYA } \\
\text { (KVA) }\end{array}$ & $\begin{array}{c}\text { TOTAL DAYA } \\
\text { INTERRUPT } \\
\text { (KVA) }\end{array}$ \\
\hline 137 & 20.700 & $8.855,06$ & 22.106 & 9.456 \\
\hline
\end{tabular}

Dari tabel kondisi diatas, didapat data gardu sejumlah 137 gardu distribusi dengan melayani total pelanggan 20.700 pelanggan, dimana terdapat pelanggan yang mengalami gangguan sebesar 8.855 pelanggan. Total daya pelanggan Penyulang Bangli yang dilayani sebelum mendapat pasokan tambahan PLTS Kayubihi yaitu $22.106 \mathrm{kVa}$ dan total daya pelanggan gangguan sebesar $9.456 \mathrm{kVa}$.

Nilai dari total daya gangguan atau interrupt akan dikalikan dengan waktu perbaikan atau repair time tiap-tiap titik beban atau load point sehingga didapat nilai $\mathrm{kWh}$ Gangguan dari pelanggan gangguan. Maka didapat nilai ENS (Energy Not Supplied) sebagai berikut :

Tabel 2.

ENS (Energy Not Supplied) Penyulang Bangli sebelum mendapat pasokan PLTS Kayubihi

\begin{tabular}{|c|c|c|c|c|}
\hline $\begin{array}{c}\text { JUMLAH } \\
\text { GARDU }\end{array}$ & $\begin{array}{c}\text { TOTAL } \\
\text { PELANG } \\
\text { GAN }\end{array}$ & $\begin{array}{c}\text { PELANG } \\
\text { GAN } \\
\text { INTERRU } \\
\text { PT }\end{array}$ & $\begin{array}{c}\text { Repair } \\
\text { Time }\end{array}$ & $\begin{array}{c}\text { ENS (Energy } \\
\text { Not } \\
\text { Supplied) }\end{array}$ \\
\hline 137 & 20.700 & $8.855,06$ & $\begin{array}{c}0-3 \\
\text { jam }\end{array}$ & $10.378,98$ \\
\hline
\end{tabular}

Maka untuk nilai indeks Energi Listrik Terselamatkan pada Penyulang Bangli dari sumber utama tanpa adanya tambahan pasokan PLTS Kayubihi adalah sebagai berikut :

Perhitungan ASIFI Penyulang Bangli Sebelum mendapat pasokan PLTS Kayubihi :

\author{
ASIFI $=\frac{\text { Jumlah kVA Gangguan }}{\Sigma \text { Total kVA Sistem yang dilayani }}$ \\ ASIFI $=\frac{9.457}{22.106}$ \\ ASIFI $=0,428$ Gangguan Per Hari
}

Perhitungan ASIDI Penyulang Bangli Sebelum mendapat pasokan PLTS Kayubihi :

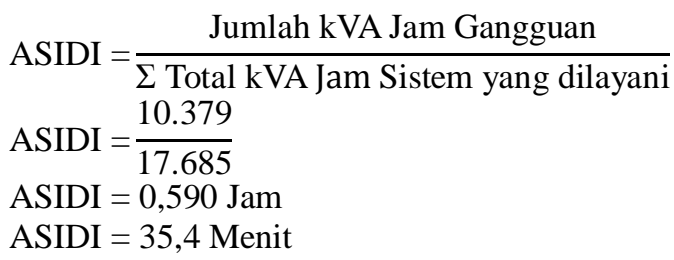

Perhitungan ENS (Energy Not Supplied) Penyulang Bangli Sebelum mendapat pasokan PLTS Kayubihi :

p-ISSN:1693 - 2951; e-ISSN: 2503-2372 
ENS $($ ENERGY NOT SUPPLIED $=10.379 \mathrm{kWh} / \mathrm{Hari}$

Perhitungan AENS (Average Energy Not Supplied) Penyulang Bangli Sebelum mendapat pasokan PLTS Kayubihi :

$$
\begin{aligned}
& \text { AENS }=\frac{\text { ENS }}{\Sigma T O T A L \text { PELANGGAN }} \\
& \text { AENS }(\text { AVERAGE ENERGY NOT SUPPLIED })=\frac{10.379}{20.700} \\
& \text { AENS }=0,501 \mathrm{kWh} / \text { Pelanggan }
\end{aligned}
$$

C. Energi Listrik Terselamatkan Penyulang Bangli Setelah mendapat pasokan PLTS Kayubihi

Sistem distribusi penyulang Bangli setelah mendapatkan pasokan energi listrik dari PLTS Kayubihi memiliki karakteristik 150 gardu distribusi dengan total pelanggan 22.977 pelanggan.

Tabel 3. Kondisi Penyulang Bangli setelah mendapat pasokan PLTS Kayubihi

\begin{tabular}{|c|c|c|c|c|}
\hline $\begin{array}{c}\text { JUMLAH } \\
\text { GARDU }\end{array}$ & $\begin{array}{c}\text { TOTAL } \\
\text { PELANGG } \\
\text { AN }\end{array}$ & $\begin{array}{c}\text { PELANGGAN } \\
\text { INTERRUPT }\end{array}$ & $\begin{array}{c}\text { TOTAL } \\
\text { DAYA } \\
\text { (KVA) }\end{array}$ & $\begin{array}{c}\text { TOTAL DAYA } \\
\text { INTERRUPT } \\
\text { (KVA) }\end{array}$ \\
\hline 150 & 22.977 & $1.276,11$ & $22.137,8$ & $1.227,95$ \\
\hline
\end{tabular}

Dari tabel kondisi diatas, didapat data gardu sejumlah 150 gardu distribusi dengan melayani total pelanggan 22.977 pelanggan, dimana terdapat pelanggan yang mengalami gangguan sebesar $1.276,11$ pelanggan. Total daya pelanggan Penyulang Bangli yang dilayani setelah mendapat pasokan tambahan PLTS Kayubihi yaitu 22.137,8 kVa dan total daya pelanggan gangguan sebesar $1.227,95 \mathrm{kVa}$.

Nilai dari total daya gangguan atau interrupt akan dikalikan dengan waktu perbaikan atau repair time tiap-tiap titik beban atau load point sehingga didapat nilai $\mathrm{kWh}$ Gangguan dari pelanggan gangguan. Maka didapat nilai ENS (Energy Not Supplied) sebagai berikut :

Tabel 4. ENS (Energy Not Supplied) Penyulang Bangli setelah mendapat pasokan PLTS Kayubihi

\begin{tabular}{|c|c|c|c|c|}
\hline $\begin{array}{c}\text { JUMLAH } \\
\text { GARDU }\end{array}$ & $\begin{array}{c}\text { TOTAL } \\
\text { PELANGG } \\
\text { AN }\end{array}$ & $\begin{array}{c}\text { PELANGGAN } \\
\text { INTERRUPT }\end{array}$ & $\begin{array}{c}\text { Repair } \\
\text { Time }\end{array}$ & $\begin{array}{c}\text { ENS (Energy } \\
\text { Not Supplied) }\end{array}$ \\
\hline 150 & 22.977 & $1.276,11$ & $\begin{array}{c}0-2 \\
\text { jam }\end{array}$ & $1.505,24$ \\
\hline
\end{tabular}

Maka untuk nilai indeks Energi Listrik Terselamatkan pada Penyulang Bangli dari sumber utama tanpa adanya tambahan pasokan PLTS Kayubihi adalah sebagai berikut :

\section{$>$ Perhitungan ASIFI Penyulang Bangli Setelah} mendapat pasokan PLTS Kayubihi :

ASIFI $=\frac{\text { Jumlah kVA Gangguan }}{\Sigma \text { Total kVA Sistem yang dilayani }}$

$\mathrm{ASIFI}=\frac{1.228}{22.138}$
ASIFI $=0,055$ Gangguan Per Hari

Perhitungan ASIDI Penyulang Bangli Setelah mendapat pasokan PLTS Kayubihi :

$$
\begin{aligned}
& \text { ASIDI }=\frac{\text { Jumlah } \mathrm{kVA} \mathrm{Jam} \mathrm{Gangguan}}{\sum \text { Total } \mathrm{kVA} \mathrm{Jam} \mathrm{Sistem} \mathrm{yang} \mathrm{dilayani}} \\
& \text { ASIDI }=\frac{1.505}{17.710} \\
& \text { ASIDI }=0,085 \mathrm{jam} / \text { pelanggan } \\
& \text { ASIDI }=5,1 \mathrm{menit} / \text { pelanggan }
\end{aligned}
$$

\section{$>$ Perhitungan ENS (Energy Not Supplied) Penyulang Bangli Setelah mendapat pasokan PLTS Kayubihi :}

ENS (ENERGY NOT SUPPLIED = $1.505 \mathrm{kWh} /$ Hari

$>$ Perhitungan AENS (Average Energy Not Supplied) Penyulang Bangli Setelah mendapat pasokan PLTS Kayubihi :

$$
\begin{aligned}
& \text { AENS }=\frac{\text { ENS }}{\Sigma \text { TOTAL PELANGGAN }} \\
& \text { AENS (AVERAGE ENERGY NOT SUPPLIED) }=\frac{1.505}{22.979} \\
& \text { AENS }=0,066 \mathrm{kWh} / \text { Pelanggan }
\end{aligned}
$$

Karakteristik yang digunakan untuk mengetahui beban puncak penyulang Bangli adalah karakteristik beban harian. Data yang digunakan untuk mengetahui beban puncak penyulang Bangli, yaitu data beban tiap jam dari pukul 00.00 23.30 selama satu bulan pada bulan Oktober 2015 dan dihitung rata-rata beban per jam. Data pada bulan Oktober akan dijadikan acuan untuk pola beban penyulang selama satu tahun. Hasil rata-rata tersebut dapat dilihat pada tabel di bawah ini:

Tabel 5.

Data beban harian per jam selama satu bulan (Sumber: PLN Batur 2015)

\begin{tabular}{|r|r|}
\hline \multicolumn{1}{|c|}{ Time } & \multicolumn{1}{|c|}{ Beban (VA) } \\
\hline $0: 00$ & 4626627,22 \\
\hline $0: 30$ & 4455788,796 \\
\hline $1: 00$ & 4333559,471 \\
\hline $1: 30$ & 4251743,55 \\
\hline $2: 00$ & 4197482,206 \\
\hline $2: 30$ & 4150568,748 \\
\hline $3: 00$ & 4119622,814 \\
\hline $3: 30$ & 4103090,076 \\
\hline $4: 00$ & 4110014,041 \\
\hline$\ldots \ldots$. & $\ldots \ldots$. \\
\hline$\ldots \ldots .$. & $\ldots \ldots$. \\
\hline $22: 30$ & 5475449,81 \\
\hline $23: 00$ & 5167121,065 \\
\hline $23: 30$ & 4864868,443 \\
\hline
\end{tabular}

Valentinus Gerald: Analisis Energi Listrik Terselamatkan ... 


\section{Rata-Rata Beban Penyulang Bangli (VA)}

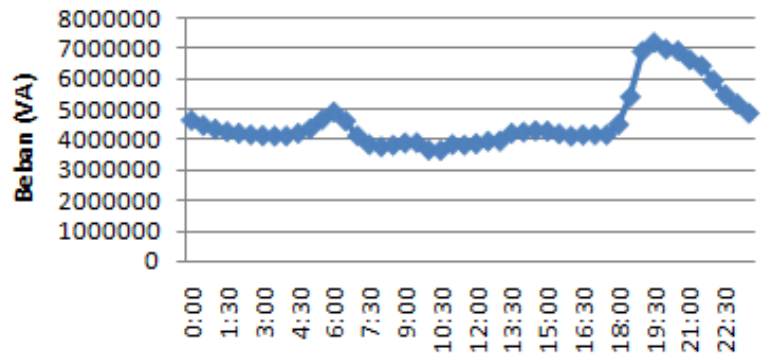

Jam

Gambar 1: Rata-Rata Beban Penyulang Bangli Tahun 2015

Keadaan Penyulang Bangli yang terinterkoneksi dengan PLTS Kayubihi mempengaruhi perhitungan susut energi berdasarkan pada beban puncak pada siang hari penyulang Bangli. Berikut adalah data pembangkitan PLTS Kayubihi dari sumber PLTS Bangklet-Bangli :

\section{Tabel 6.}

Data beban harian per jam selama satu bulan (Sumber: PLN Batur 2015)

\begin{tabular}{|c|c|}
\hline Jam & Rata-Rata $(\mathrm{KW})$ \\
\hline $6: 00$ & 0,58 \\
\hline $7: 00$ & 96,45 \\
\hline $8: 00$ & 290,38 \\
\hline $9: 00$ & 469,86 \\
\hline $10: 00$ & 594,76 \\
\hline $11: 00$ & 714,04 \\
\hline $12: 00$ & 737,8 \\
\hline $13: 00$ & 708,76 \\
\hline $14: 00$ & 548,17 \\
\hline $15: 00$ & 420,23 \\
\hline $16: 00$ & 227,56 \\
\hline $17: 00$ & 71,78 \\
\hline $18: 00$ & 0,01 \\
\hline
\end{tabular}

Valentinus Gerald: Analisis Energi Listrik Terselamatkan ...

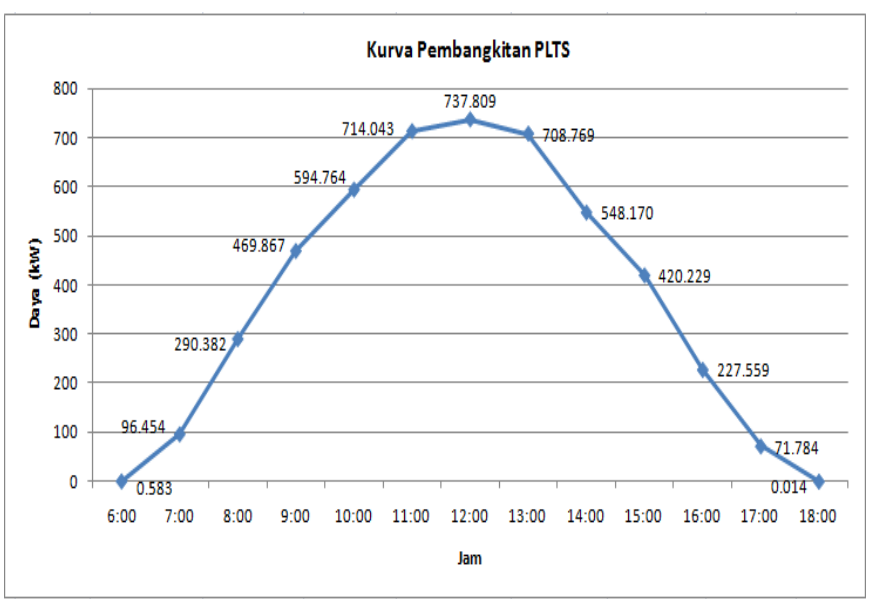

Gambar 2: Rata-Rata Daya Pembangkitan PLTS Kayubihi Tahun 2015 (sumber $=$ PLTS Bangklet-Bangli)

\section{Load Factor pada Penyulang Bangli}

Seperti yang kita ketahui pada tabel diatas bahwa Penyulang Bangli mempunyai beban rataan 4605,42 kVA dan memiliki beban puncak siang sebesar 4903,44 kVA. Sebagaimana kita ketahui penggunaan beban puncak siang penyulang digunakan karena PLTS tidak bekerja selama 24 jam. Maka untuk mendapatkan load factor, yaitu:

$$
\begin{aligned}
& F_{L D}=\frac{B_{r}(\text { beban rata rata })}{B_{p}(\text { beban puncak })} \\
& F_{L D}=\frac{4605,42}{4903,44}=0,94
\end{aligned}
$$

\section{$>\quad$ Loss Factor pada Penyulang Bangli}

Maka kita mengetahui hasil load factor maka selanjutnya dapat dihitung loss factor pada penyulang Bangli, yaitu:

$$
\begin{aligned}
& F_{L S}=0,15 F_{L D}+(1-0,15) F_{L D}^{2} \\
& F_{L S}=(0,15 X 0,94)+(1-0.15)(0,94)^{2}=0,892
\end{aligned}
$$

\section{Susut Energi Penyulang Bangli}

Dengan hasil susut energi pada penyulang Bangli pada indeks ENS (EnergyNot Supplied) Penyulang Bangli maka dapat dihitung susut energi ENS Penyulang Bangli selama setahun yaitu:

1. Susut energi penyulang Bangli Tanpa PLTS:

Energy Not Supplied ${ }_{\text {TANPA PLTS }} \times$ Loss Factor $\times 365$

$$
\begin{aligned}
& =10.379 \mathrm{kWh} \times 0,892 \times 365 \\
& =3.379 .194,82 \mathrm{kWh}
\end{aligned}
$$

2. Susut energi penyulang Bangli dengan PLTS: Energy Not Supplied ${ }_{\text {DGN PLTS }} \times$ Loss Factor $\times 365$

$$
\begin{aligned}
& =1.505 \mathrm{kWh} \times 0,892 \times 365 \\
& =489.997,9 \mathrm{kWh}
\end{aligned}
$$$$
\text { p-ISSN:1693 - 2951; e-ISSN: 2503-2372 }
$$ 
Dari hasil perhitungan di atas dapat dilihat bahwa penyulang Bangli tanpa PLTS susut energi sebesar 3.379.194,82 kWh. Penyulang Bangli dengan PLTS menghasilkan susut energi sebesar 489.997,9 kWh. Terjadi penurunan susut energi ini dikarenakan adanya bantuan daya dari PLTS sehingga proses penyaluran daya pada penyulang semakin baik dan menyebabkan susut energi pada jaringan tersebut menurun.

\section{$>$ Selisih Susut Energi Penyulang Bangli}

Berikut ini merupakan selisih susut energi penyulang bangli tanpa PLTS dan dengan PLTS:

Susut Energi Tanpa PLTS - Susut Energi Dengan PLTS

$=3.379 .194,82 \mathrm{kWh}-489.997,9 \mathrm{kWh}$

$=2.889 .196,92 \mathrm{kWh}$

Persentase penurunan susut energi ;

$=($ susut energi dengan PLTS : susut energi tanpa PLTS $) \times$ $100 \%)$

$=(489.997,9: 3.379 .194,82) \times 100 \%$

$=14,5 \%$

\section{$>\quad$ NDE (Non Delivery Energy)}

Karena rata-rata dari konsumen PT. PLN (Persero) Area Bali Timur memiliki golongan tegangan rendah dan satu tegangan menengah, maka untuk NDE (Non Delivery Energy). Dengan tarif listrik adjustment per desember Bali adalah Rp 1.507,00 (PLN,2015), maka NDE (Non Delivery Energy) dalam rupiah adalah sebagai berikut:

$\mathrm{NDE}_{\text {(rupiah) }}=$ Selisih Susut energi X tarif dasar listrik

$$
\begin{aligned}
& =2.889 .196,92 \mathrm{kWh} \text { X Rp. 1.507,00 (rupiah) } \\
& =\text { Rp. 4.354.019.758,44 }
\end{aligned}
$$

Dari hasil perhitungan selisih Non Delivery Energy yang terjadi sebesar 2.889.196,92 kWh per tahun dengan penurunan susut energi sebesar $14,5 \%$ dan selisih susut energi dalam rupiah sebesar Rp. 4.354.019.758,44. Dilihat dari hasil selisih susut energi di atas nilainya cukup besar jadi dengan adanya PLTS sangat berdampak baik pada penyulang Bangli.

\section{KESIMPULAN}

Berdasarkan hasil perhitungan pada bagian sebelumnya pada Tugas Akhir ini dapat ditarik beberapa simpulan sebagai berikut :
1. Perhitungan Energi listrik terselamatkan pada Penyulang Bangli sebelum mendapat pasokan tambahan PLTS Kayubihi memiliki indeks keandalan ASIDI 0,428 Jam atau 25,67 menit, ASIFI 0,085 Gangguan, ENS (Energy Not Supplied) $10.379 \mathrm{kWh}$, AENS 0,501 kWh/Pelanggan

2. Perhitungan Energi listrik terselamatkan pada Penyulang Bangli setelah mendapat pasokan tambahan PLTS Kayubihi memiliki indeks keandalan ASIDI 0,085 Jam atau 5,1 menit/pelanggan/hari, ASIFI 0,055 Gangguan/pelanggan/hari, ENS (Energy Not Supplied) $1.505 \mathrm{kWh}$, AENS 0,066 kWh/Pelanggan.

3. Hasil susut energi pada penyulang Bangli pada indeks ENS (EnergyNot Supplied) Penyulang Bangli maka dapat dihitung susut energy ENS Penyulang Bangli selama setahun yaitu susut energi penyulang Bangli tanpa PLTS 3.379.194,82 kWh per tahun dan susut energi penyulang Bangli dengan PLTS 489.997,9 kWh per tahun. Selisih susut energi menjadi 2.889.196,92 kWh dan untuk persentase susut energy penyulang bangli tanpa PLTS dan dengan PLTS sebesar 14,5\%.

4. Dengan demikian PLN Area Bali Timur dapat menghemat pengeluaran NDE (Non Delivery Energy) sebesar Rp. 4.354.019.758,44 / Tahun (empat miliar tiga ratus lima puluh empat juta sembilan belas ribu tujuh ratus lima puluh delapan rupiah empat puluh empat sen).

\section{REFERENSI}

[1] Xie, K. Zhou, J. dan Billinton, R. 2008. Fast algorithm for the reliability evaluation of large scale electrical distribution networks using the section technique.IET Gener.Transm.Distrib. Vol. 2, No.5, pp. 701-707.

[2] Abisatya, Nyoman. 2014. Analisis Pengaruh Lokasi Distributed Generation Terhadap Susust Daya Pada Penyulang Abang Di Karangasem. E-Journal SPEKTRUM. Vol.1, No.1. Universitas Udayana.

[3] Natha Riadnyana, Kadek. 2015. Pengaruh Beroperasinya PLTS Kayubihi Terhadap Susut Energi Dan Keandalan Penyulang Bangli. EJournal SPEKTRUM. Vol.2, No.1. Universitas Udayana.

[4] Gina, Juniastra. 2012. Susut Energi Pada Sistem Kelistrikan Bali Sesuai Rencana Operasi Sutet 500 kV. E-Journal SPEKTRUM Vol 1, No. 2. Universitas Udayana.

[5] Gonen, Turan. 2007. "Electric Power Distribution System Engineering" CRC Press Taylor \& Francis Group. United States of America : California State University Sacramento, California.

[6] Praditama, Fery. 2014. Analisis Keandalan dan Nilai Di Penyulang Pujon PT. PLN (Persero) Area Malang. Malang: Universitas Brawijaya.

[7] Partawan, Nyoman. 2014. "Studi Perbandingan Keandalan Sistem Distribusi 20 kV Menggunakan Metode Section Technique dan RNEA pada Penyulang Renon”(Tugas Akhir). E-Journal SPEKTRUM Vol. 1, No. 1. Denpasar : Universitas Udayana. 